\begin{tabular}{|l|l|l|l|l|l|}
\hline J. Tek. Ling & Vol. 10 & No. 2 & Hal. 145 - 151 & Jakarta, Mei 2009 & ISSN 1441-318X \\
\hline
\end{tabular}

\title{
PENURUNAN KADAR KROM (Cr) DENGAN MENGGUNAKAN BIOMASA AMPAS TEBU SECARA BIO-ADSORBSI
}

\author{
Yasril, Heru Subaris Kasjono, dan Sri Puji Ganefati \\ Jurusan Kesehatan Lingkungan, Poltekkes Depkes Yogyakarta
}

\begin{abstract}
Chrome is a substance belong to high toxicity heavy metal group which can cause both acute and chronic poisoning. One of the methods that can be used to reduce its concentration is biosorbtion with bagasse biomass. The objectives of the study were to understand the chrome concentration before and after absorbed, as well as to understand the amount of the most effective biomass.

The study was an experimental with three treatments of which consisted of eight repetitions. The sample was synthetic liquid waste and the treatment absorbent was bagasse biomass which was processed as activated carbon of 10, 15, and 20 grams weight. The chrome concentration were measured by using AAS method. The results showed that the chrome concentration before treated was 10,196 $\mathrm{mg} / \mathrm{l}$, and the average of the reduction from the three absorbents weight were: $0.174 \mathrm{mg} / \mathrm{l}, 0,099 \mathrm{mg} / \mathrm{l}$, and 0,011 $\mathrm{mg} / \mathrm{l}$ respectively.

It can be concluded that there were reduction differences amongst the three treatments, and $20 \mathrm{gr}$ absorbent was the most effective one (99.88\% reduction). It is advised for further study to apply the bagasse for processing liquid waste from industrial activities.
\end{abstract}

Keywords: Bagasse biomass, Chrome

\section{PENDAHULUAN}

\subsection{Latar Belakang}

Suatu tatanan lingkungan hidup dapat tercemar atau menjadi rusak oleh berbagai hal. Namun yang paling utama dari sekian banyak penyebab tercemarnya suatu tatanan lingkungan adalah limbah.

Pencemaran yang dapat menghancurkan tatanan lingkungan hidup, biasanya berasal dari limbah-limbah yang sangat berbahaya dalam arti memiliki daya racun (toksisitas) yang tinggi. Limbah-limbah yang sangat beracun pada umumnya merupakan limbah kimia, apakah itu berupa persenyawaan-persenyawaan kimia atau hanya dalam bentuk unsur atau ionisasi.
Biasanya senyawa kimia yang sangat beracun bagi organisme hidup dan manusia adalah senyawa-senyawa yang mempunyai bahan aktif dari logam-logam berat.

Salah satu jenis logam berat yang berpotensi mencemari lingkungan dan bahkan dapat mengganggu kesehatan manusia adalah krom (Cr). Sebagai logam berat, $\mathrm{Cr}$ termasuk logam yang mempunyai daya racun tinggi. Sifat racun yang di bawa oleh logam ini juga dapat mengakibatkan terjadinya keracunan akut dan keracunan kronis.

Mengingat bahaya yang ditimbulkan oleh logam krom maka sebelum dibuang ke lingkungan sebaiknya perlu dilakukan pengolahan terlebih dahulu. Salah satu pengolahannya adalah dengan metode biosorbsi dengan memanfaatkan media biomasa. 
Penelitian tentang penyerapan ion-ion logam oleh biomaterial biologi telah pernah dilakukan oleh peneliti terdahulu, baik serapan oleh organisme hidup maupun secara biomassanya (dikeringkan).

Untuk itu pada penelitian ini penulis mencoba memanfaatkan biomasa ampas tebu dimana penyerapan ion-ion logam berat oleh biomaterial ampas tebuterjadi melalui proses biosorbsi dimana terjadinya adsorbsi kation logam berat oleh dinding sel media bio yang bemuatan negatif.

\subsection{Rumusan Masalah}

Berdasarkan latar belakang diatas maka yang menjadi permasalahan dalam penelitian ini adalah apakah kadar krom (Cr) dapat diturunkan dengan menggunakan ampas tebu secara biosorbsi.

\subsection{Tujuan Umum Penelitian}

Untuk mengetahui penurunan kadar krom $(\mathrm{Cr})$ dengan menggunakan ampas tebu dengan metode biosorbsi.

\subsection{Tujuan Khusus}

1. Diketahui kadar krom sebelum penambahan ampas tebu

2. Diketahui penurunan kadar krom dengan menambahkan ampas tebu sebanyak 10 gram, 15 gram dan 20 gram dalam $100 \mathrm{ml}$ sampel.

3. Diketahui perbedaan masing-masing perlakuan (10 gr, $15 \mathrm{gr}$ dan $20 \mathrm{gr}$ ) dalam menurunkan kadar krom

\subsection{Manfaat Penelitian}

Hasil penelitian ini dapat dijadikan sebagai salah satu alternatif dalam upaya mengurangi sampah organik serta mengoptimalkan penggunaan ampas tebu yan merupakan limbah padat perkotaan. Selain itu juga dapat dimanfaatkan oleh industri dalam pengolahan limbahnya terutama limbah yang mengandung $\mathrm{Cr}$.

\subsection{Ruang Lingkup Penelitian}

Penelitian ini difokuskan pada penurunan kadar krom ( $\mathrm{Cr}$ ) dengan menggunakan ampas tebu secara biosorpsi dengan jumlah penambahan ampas tebu yang bervariasi yaitu 10gr, 15 gr dan 20 gr pada tiap $100 \mathrm{ml}$ sampel.

\subsection{Jenis Penelitian}

Penelitian ini bersifat eksperimen untuk mengetahui kemampuan ampas tebu dalam menurunkan kadar krom pada limbah cair sintetis.

\subsection{Lokasi dan Waktu Penelitian}

Penelitian ini dilaksanakan di laboratorim kimia dasar Kopertis Wilayah $X$ dan Balai Riset dan Standardisasi Industri (Baristand) Padang pada bulan Juni sampai dengan bulan Juli 2008.

\subsection{Objek Penelitian}

Yang menjadi objek dalam penelitian ini adalah limbah cair sintetis yaitu garam krom nitrat $\left(\mathrm{Cr}\left(\mathrm{NO}_{3}\right)_{3} \cdot 9 \mathrm{H}_{2} \mathrm{O}\right)$ yang mengandung ion krom $(\mathrm{Cr})$ dengan konsentrasi sebesar $10 \mathrm{mg} / \mathrm{l}$ dan absorben yang digunakan yaitu karbon aktif ampas tebu yang telah dihaluskan dengan ukuran partikel 500 micron.

\subsection{Analisa Data}

Pengolahan data dilakukan secara komputerisasi yaitu dengan menggunakan SPSS, selanjutnya dilakukan analisa bivariat yaitu dengan uji T-test dan anova untuk melihat rata-rata penurunan kadar krom sebelum dan setelah di absorbsi serta melihat perbedaan antara masing-masing perlakuan dan mengetahui jumlah ampas tebu yang paling efektif dalam penurunan kadar krom. 


\subsection{Instrument}

Untuk mengetahui kadar krom sebelum dan setelah diabsorbsi diukur dengan menggunakan Atomic Absorption Spectrophotometer (AAS). yang berbeda pada setiap perlakuan. Pemeriksaan kadar $\mathrm{Cr}$ menggunakan ampas tebu yang telah dijadikan arang aktif dilakukan sebanyak tiga perlakuan dan masing-masing perlakuan dilakukan delapan kali pengulangan sedangkan untuk pemeriksaan sebelumperlakuan hanya dilakukan satu kali pengulangan karena kadar $\mathrm{Cr}$ dianggap homogen. Hasil pemeriksaan laboratorium terhadap penurunan kadar $\mathrm{Cr}$ adalah sebagai berikut:

Tabel 1. Hasil Pengukuran Terhadap Kadar Cr Sebelum dan Setelah Diabsorbsi dengan Absorben Ampas Tebu dengan Berat 10 gram.

\begin{tabular}{|c|c|c|c|c|c|}
\hline \multirow{2}{*}{ Pengulangan } & \multicolumn{2}{|c|}{ Kadar Cr (mg/l) } & Penurunan (mg/l) & $\begin{array}{c}\text { Efisiensi } \\
\text { Penurunan (\%) }\end{array}$ & \multirow{2}{*}{ P. value } \\
\cline { 2 - 5 } & Sebelum & Sesudah & & 98,75 & \\
\hline I & 10,196 & 0,127 & 10,069 & 98,85 \\
\hline II & 10,196 & 0,117 & 10,079 & 96,47 \\
\hline III & 10,196 & 0,360 & 9,836 & 97,92 \\
\hline IV & 10,196 & 0,212 & 9,984 & 98,34 & \multirow{2}{*}{0,001} \\
\hline V & 10,196 & 0,169 & 10,027 & 99,08 & \\
\hline VI & 10.196 & 0,094 & 10,012 & 98,47 & \\
\hline VIIII & 10,196 & 0,156 & 10,040 & 99,08 & \\
\hline Jumlah & 10,196 & 0,094 & 10,102 & $\mathbf{7 8 6 , 3 1}$ & \\
\hline Rata-rata & $\mathbf{8 1 , 5 6 8}$ & $\mathbf{1 , 3 9 5}$ & $\mathbf{7 9 , 7 2 3}$ & $\mathbf{9 8 , 2 9}$ & \\
\hline
\end{tabular}

\section{HASIL DAN PEMBAHASAN}

\subsection{Hasil Penelitian}

Penelitian ini dilaksanakan di Laboratorium Kimia Dasar Kopertis Wilayah $X$ dan Baristand Indag Padang selama satu bulan. Dalam penelitian ini sampel yang digunakan adalah limbah cair sintetis yang mengandung unsur krom $(\mathrm{Cr})$ dengan konsentrasi $10 \mathrm{mg} / \mathrm{l}$. Absorben yang digunakan adalah ampas tebu yang dijadikan sebagai arang aktif dengan ukuran partikel sebesar 500 micron.

Penelitian ini dilakukan untuk melihat kemampuan ampas tebu dalam menurunkan kadar $\mathrm{Cr}$ pada limbah sintetis dengan penambahan jumlah ampas tebu
Berdasarkan tabel 1. dapat dilihat rata-rata kadar krom sebelum diabsorbsi dengan adalah 10, $169 \mathrm{mg} / \mathrm{l}$ dan setelah diabsorbsi dengan jumlah ampas tebu sebanyak 10 gram adalah 0,174 mg/l dengan persentase penurunan sebesar 98,29\%. Berdasarkan hasil uji statistik pada alpha $5 \%$ didapat nilai $\mathrm{p}=0,001$ ( $p<a ́$ ) maka dapat disimpulkan bahwa ada perbedaan yang signifikan antara kadar krom sebelum dan setelah diabsorpsi.

Berdasarkan tabel.2 dapat dilihat rata-rata kadar krom sebelum diabsorbsi dengan adalah 10, $169 \mathrm{mg} / \mathrm{l}$ dan setelah diabsorbsi dengan jumlah ampas tebu sebanyak 15 gram adalah 0,099 mg/l dengan persentase penurunan sebesar 99,03 \%. Berdasarkan hasil uji statistik 
pada alpha $5 \%$ didapat nilai $p=0,001$ ( $p<a ́$ ) maka dapat disimpulkan bahwa ada perbedaan yang signifikan antara kadar krom sebelum dan setelah diabsorpsi.
Berdasarkan tabel 3. dapat dilihat rata-rata kadar krom sebelum diabsorbsi dengan adalah 10, $169 \mathrm{mg} / \mathrm{l}$ dan setelah diabsorbsi dengan jumlah ampas tebu

Tabel 2. Hasil Pengukuran Terhadap Kadar Cr Sebelum dan Setelah Diabsorbsi dengan Absorben Ampas Tebu dengan Berat 15 gram.

\begin{tabular}{|c|c|c|c|c|c|}
\hline \multirow{2}{*}{ Pengulangan } & \multicolumn{2}{|c|}{ Kadar Cr (mg/l) } & Penurunan (mg/l) & $\begin{array}{c}\text { Efisiensi } \\
\text { Penurunan (\%) }\end{array}$ & P. value \\
\cline { 2 - 5 } & Sebelum & Sesudah & & 98,91 & \\
\hline I & 10,196 & 0,111 & 10,085 & 99,25 & \\
\hline II & 10,196 & 0,076 & 10,120 & 97,82 & \\
\hline III & 10,196 & 0,222 & 9,974 & 99,24 & \multirow{2}{*}{0,001} \\
\hline IV & 10,196 & 0,077 & 10,119 & 99,26 & \\
\hline V & 10,196 & 0,075 & 10,121 & 98,70 & \\
\hline VI & 10.196 & 0,133 & 10,063 & 99,07 & \\
\hline VII & 10,196 & 0,095 & 10,101 & 99,99 & \\
\hline VIII & 10,196 & 0,001 & 10,195 & $\mathbf{7 9 2 , 2 4}$ \\
\hline Jumlah & $\mathbf{8 1 , 5 6 8}$ & $\mathbf{0 , 7 9 0}$ & $\mathbf{8 0 , 7 7 8}$ & $\mathbf{9 9 , 0 3}$ & \\
\hline Rata-rata & $\mathbf{1 0 , 1 9 6}$ & $\mathbf{0 , 0 9 9}$ & $\mathbf{1 0 , 0 9 7}$ & \\
\hline
\end{tabular}

Tabel 3. Hasil Pengukuran Terhadap Kadar Cr Sebelum dan Setelah Diabsorbsi dengan Absorben Ampas Tebu dengan Berat 20 gram.

\begin{tabular}{|c|c|c|c|c|c|}
\hline \multirow[b]{2}{*}{ Pengulangan } & \multicolumn{2}{|c|}{ Kadar Cr (mg/l) } & \multirow{2}{*}{ Penurunan (mg/l) } & \multirow{2}{*}{$\begin{array}{c}\text { Efisiensi } \\
\text { Penurunan } \\
(\%)\end{array}$} & \multirow[b]{2}{*}{ P. value } \\
\hline & Sebelum & Sesudah & & & \\
\hline I & 10,196 & 0,089 & 10,107 & 99,13 & \multirow{10}{*}{0,001} \\
\hline II & 10,196 & 0,001 & 10,195 & 99,99 & \\
\hline III & 10,196 & 0,001 & 10,195 & 99,99 & \\
\hline IV & 10,196 & 0,001 & 10,195 & 99,99 & \\
\hline V & 10,196 & 0,001 & 10,195 & 99,99 & \\
\hline VI & 10.196 & 0,001 & 10,195 & 99,99 & \\
\hline VII & 10,196 & 0,001 & 10,195 & 99,99 & \\
\hline VIII & 10,196 & 0,001 & 10,195 & 99,99 & \\
\hline Jumlah & 81,568 & 0,096 & 81,472 & 799,06 & \\
\hline Rata-rata & 10,196 & 0,012 & 10,185 & 99,88 & \\
\hline
\end{tabular}


sebanyak 20 gram adalah 0,012 mg/l dengan persentase penurunan sebesar 99,88\%. Berdasarkan hasil uji statistik pada alpha $5 \%$ didapat nilai $p=0,001$ ( $p<a ́$ ) maka dapat disimpulkan bahwa ada perbedaan yang signifikan antara kadar krom sebelum dan setelah diabsorpsi.

Untuk mengetahui berat ampas tebu yang paling efekif dalam menurunkan kadar krom maka dilakukan uji Anova yang hasilnya seperti pada tabel berikut: logam yang mempunyai daya racun tinggi. Sifat racun yang dibawa oleh logam ini juga dapat mengakibatkan terjadinya keracunan akut dan kronis.

Untuk itu berbagai upaya pengolahan telah dilakukan untuk meminimalisir kadar Cr yang akan dibuang ke lingkungan, salah satu pengolahannya adalah dengan metode biosorbsi dengan memanfaatkan berbagai jenis biomasa yang dapat menyerap kadar Cr.

Tabel 4. Distribusi Rata-rata Kadar Krom(Cr) Setelah Diabsorbsi Dengan Ampas Tebu.

\begin{tabular}{|c|c|c|c|c|}
\hline Variable & Mean & SD & $95 \% \mathrm{Cl}$ & \multirow{2}{*}{ P. value } \\
\cline { 1 - 4 } Berat $10 \mathrm{gr}$ & 0,174 & 0,083 & $0,105-0,244$ & \multirow{2}{*}{0,001} \\
\cline { 1 - 3 } Berat $15 \mathrm{gr}$ & 0,999 & 0,063 & $0,046-0,151$ & \\
\hline Berat $20 \mathrm{gr}$ & 0,012 & 0,031 & $-0,014-0,038$ \\
\hline
\end{tabular}

Berdasarkan tabel 4. dapat dilihat bahwa rata-rata penurunan kadar $\mathrm{Cr}$ pada ampas tebu dengan berat 10 gram adalah $0,174 \mathrm{mg} / \mathrm{l}$ dengan standar deviasi $0,083 \mathrm{mg} / \mathrm{l}$ sedangkan pada ampas tebu dengan berat $15 \mathrm{gram}$ adalah $0,099 \mathrm{mg} / \mathrm{l}$ dengan standar deviasi $0,063 \mathrm{mg} / \mathrm{l}$ dan pada ampas tebu dengan berat 20 gram adalah $0,012 \mathrm{mg} / \mathrm{l}$ dengan standar deviasi $0,031 \mathrm{mg} / \mathrm{l}$.

Hasil uji statistik pada alpha $5 \%$ didapat nilai $p=0,001$ ( $p<a ́$ ) maka dapat disimpulkan bahwa ada perbedaan antara masing-masing perlakuan dan yang paling signifikan yaitu pada perlakuan ke tiga dengan persentase penurunan mencapai $99,88 \%$.

\subsection{Pembahasan}

Kromium ( $\mathrm{Cr}$ ) telah dimanfaatkan secara luas dalam kehidupan manusia. Logam ini sangat banyak digunakan oleh perindustrian, diantaranya adalah industri tekstil, penyamakan, pencelupan serta masih banyak lagi kegunaannya (Palar, 2004:136)1). Sebagai logam berat, $\mathrm{Cr}$ termasuk
Dalam proses absorbsi yang dilakukan adalah menggunakan biomasa ampas tebu yang merupakan salah satu alternatif yang dapat dimanfaatkan dalam menurunkan kadar Cr. Ampas tebu yang telah dijadikan arang aktif dihaluskan sehingga ukuran partikelnya menjadi 500 micron. Karbon aktif ampas tebu yang telah halus dimasukkan kedalam suatu kolom. Melalui eksperimen ini dilakukan tiga kali perlakukan dan pada masing-masing perlakuan dilakukan delapan kali pengulangan.

Sampel yang digunakan adalah limbah cair sintetis yang dibuat dari garam krom nitrat $\left(\mathrm{Cr}\left(\mathrm{NO}_{3}\right)_{3} \cdot 9 \mathrm{H}_{2} \mathrm{O}\right)$ dengan kadar krom sebesar $10 \mathrm{mg} / \mathrm{l}$. Sampel yang telah disediakan dialirkan kedalam kolom yang telah berisi karbon aktif ampas tebu. Jumlah sampel yang dialirkan sebanyak $100 \mathrm{ml}$ dan proses absorbsi berlangsung selama $\pm 2 \mathrm{jam}$. Setelah diabsorbsi dengan ampas tebu dengan berat 10 gram ratarata kadar Cr adalah 0,174 mg/l (98,29\%), pada ampas tebu dengan berat $15 \mathrm{gram}$ rata-rata kadar Cr adalah 0,099 mg/l (99,03 $\%$ ) sedangkan pada penambahan ampas tebu dengan berat 20 gram adalah 0,011 $\mathrm{mg} / \mathrm{l}(99,89 \%)$. 
Pada tabel 1 , yaitu pada perlakuan pertama dengan jumlah ampas tebu sebanyak 10 gram diketahui bahwa jumlah penurunan kadar krom pada masingmasing pengulangan bervariasi hal ini disebabkan karena kepadatan absorben dalam kolom tidak sama sehingga mempengaruhi jumlah penurunan kadar $\mathrm{Cr}$, begitu juga pada perlakuan kedua (tabel 2) dan perlakuan ketiga (tabel 3). Menurut Rahayu ${ }^{2}$ makin tebal arang makin besar kadar penurunan logam dan makin banyak waktu kotak makin besar juga penurunan kadar logamnya. Selain itu semakin luas permukaan absorben maka daya serap absorben semakin besar.

Berdasarkan KepMenLH No.51 Tahun 1995 tentang baku mutu limbah cair bagi kegiatan industri disebutkan bahwa kadar maksimum $\mathrm{Cr}$ yang dibuang ke lingkungan adalah 0,5-1 mg/l. Dengan demikian kadar $\mathrm{Cr}$ yang melebihi kadar maksimum sebelum dibuang ke lingkungan harus dilakukan pengolahan terlebih dahulu. Penelitian yang telah dilakukan oleh Helmi3) dengan menggunakan jamur merang diperoleh hasil penurunan kadar $\mathrm{Cr}$ sebesar 84, 3 \% sedangkan dengan menggunakan biomasa ampas tebu penurunannya mencapai 99,88 \% dengan waktu kontak relatif singkat yaitu selama 2 jam. Kemungkinan hal ini disebabkan karena kandungan karbon aktif pada ampas tebu cukup tinggi yaitu sebesar 23,7 \% sehingga mempunyai kemampuan serap yang cukup baik. Selain itu serapan logam oleh ampas tebu disebabkan karena ampas tebu mengandung serat yaitu lignin, selulosa dan hemiselulosa yang mengandung banyak gugus hidroksil dalam strukturnya ${ }^{4)}$

Untuk aplikasi dilapangan, kemugkinan efisiensi penyerapan ion logam krom dalam limbah cair industri berkurang jika dibandingkan dengan penyerapan ion krom yang terdapat dalam limbah cair sintetis. Hal ini diduga karena adanya ion-ion logam lain yang dapat saling berkompetisi dalam berikatan dengan sisi aktif dari karbon aktif ampas tebu ${ }^{4}$. Selain itu suatu kation dengan daya mempolarisasi yang tinggi disenangi oleh ligan sebagai atom pusat muatan positif berkerapatan tinggi sehingga menghasilkan interaksi yang kuat karena kemampuan ion logam membentuk kompleks tergantung pada daya mempolarisasi.

\section{KESIMPULAN DAN SARAN}

\subsection{Kesimpulan}

Setelah dilakukan penelitian tentang penurunan kadar krom $(\mathrm{Cr})$ dengan menggunakan biomasa ampas tebu secara biosorpsi maka diperoleh kesimpulan sebagai berikut:

1. Kadar krom sebelum diabsorpsi adalah 10,196 mg/l.

2. Kadar krom setelah diabsorpsi dengan jumlah ampas tebu sebanyak 10 gram adalah 0,174 mg/l, dengan jumlah ampas tebu sebanyak 15 gram adalah 0,097 mg/l dan dengan jumlah ampas tebu sebanyak 20 gram adalah 0,012 $\mathrm{mg} / \mathrm{l}$.

3. Ada perbedaan masing-masing perlakuan dalam menurunkan kadar krom pada limbah cair sintetis dan pada perlakuan ke tiga yaitu dengan penambahan ampas tebu sebanyak 20 gram sangat efektif dalam menurunkan kadar krom dengan persentase penurunan mencapai $99,88 \%$.

\subsection{Saran}

1. Bagi pedagang tebu sebaiknya ampas tebu yang dihasilkan diolah menjadi karbon aktif ampas tebu sehingga ampas yang dihasilkan memiliki nilai jual serta dapat dimanfaatkan oleh industri dalam mengolah air limbah yang dihasilkannya. 
2. Bagi perindustrian yang menghasilkan limbah logam berat sedapat mungkin memanfaatkan ampas tebu untuk menurunkan kadar logam terutama logam krom (Cr) sebelum dibuang ke lingkungan.

3. Untuk peneliti selanjutnya agar dapat melanjutkan penelitian ini dengan memperhatikan waktu kontak dan $\mathrm{pH}$ sehingga dapat diketahui waktu dan $\mathrm{pH}$ optimum dari karbon aktif ampas tebu dalam menyerap logam selain itu diharapkan juga untuk dapat melakukan uji langsung pada air limbah yang berasal dari limbah hasil kegiatan industri.

\section{DAFTAR PUSTAKA}

1. Palar, Heryanto, 2004 Pencemaran Dan Toksikologi Logam Berat, Jakarta: Rineka Cipta

2. Rahayu, Tuti, 2004 Karakteristik Air Sumur Dangkal di Wilayah Kartasura dan Upaya Penjernihannya di akses dari http//www.eprints.ums.ac.id

3. Helmi, 2005 Pemanfaatan Jamur Merang Untuk Menurunkan Kadar Logam Krom Dalam Limbah Cair Industri Pelapisan Logam Dengan Proses Biosorpsi di akses dari http// www.library.usu.ac.id 